\title{
A Naturalistic Study of Art Choices \\ in a Preschool Setting \\ Karen Thomas
}

Freedom and discipline, according to Whitehead (1929), are the two essentials of education. Whitehead described the relationship of freedom and discipline as a rhythm or cycle that pervades all mental development. In his opinion, much past educational failure was due to neglect of attention to the importance of this rhythm. Freedom involves the opportunity to pursue one's interests, that is, to choose according to one's own initiatives. Discipline involves the acquisition of knowledge and skills about particular subjects. Students at different stages, involved in different subjects, need different balances of freedom and discipline. Initiative and training are both necessary, but finding the correct balance is a difficult problem.

The relationship of freedom and discipline has been a matter of debate both in early childhood education and art education (Lazerson, 1972; Johnson, 1965). The child-centered movement in the early 1900 s influenced both early childhood education and art education. In early childhood education, emphasis on the uniqueness and importance of childhood led to the development of kindergartens and preschools characterized by a more flexible and playful environment and structure than the primary school classrooms. In the field of art education, this emphasis led to art programs that stressed developing each child's 
creativity and the need to allow this creativity to be expressed unhindered by adults (Lowenfeld, 1967; Steele, 1926; Cane, 1926). In both fields, there have been those who advocated programs with a more structured emphasis. In early childhood education, both Froebel and Montessori advocated an education that was more flexible than traditional education, but one that is viewed as highly structured by many contemporary childcentered advocates (Lazerson, 1972). In art education, there are those who caution against freedom without guidance (Johnson, 1965; Barkan, 1963; Clark, Day, \& Greer, 1987). Thus, the balance of freedom and discipline is an issue of importance in the areas of early childhood education and art education.

With the current emphasis on excellence in education, the question of how to structure curricula becomes very important. Should art curricula be structured around the needs and interests of the child with an emphasis on independence, creativity, and decision-making or around important aspects of the discipline with an emphasis on acquisition of knowledge and skills? Advocates of each perspective view the other perspective as hampering students' artistic development. However, arguments against an opposing perspective are typically based on philosophical assumptions concerning the nature of curricula and children's supposed responses rather than empirical evidence.

In order to better understand opposing positions in regard to freedom and discipline it would be helpful for art educators to know how these opposing positions influence actual classroom practices and how 
students respond to these practices. One issue that could be examined is the nature of artistic alternatives and limits present in art education settings that are structured around specific philosophic stances and the responses of actual students to these alternatives and limits as they effect their opportunity to make art choices. Research of this topic would be useful in (1) documenting what actually happens in the classroom, (2) providing art educators with insights for the development and implementation of curricula, and (3) providing a basis for further research concerning the appropriate balances of freedom and discipline in art education for children at different stages and in different contexts. In this study I propose to focus on the role of choice in art as it is found in a child-centered preschool and on the responses by preschool children to the opportunity to choose among art alternatives and to limits on the opportunity of choice.

\section{Statement of the Research Problem}

The purpose of this study is to examine and describe the art alternatives and art limits within the context of a preschool classroom, to describe characteristic responses of preschool children to these alternatives and limits, and to create a model illustrating the relationship of art alternatives, art limits, and children's responses that could be used in generating substantive theory that is grounded in data systematically obtained from the context (Glasser \& Strauss, 1967). The following questions guided the research activity:

Working Papers in Art Education 1988 
1. What are the characteristics of the art activities in which the children participate?

2. What are the art alternatives offered to children in the preschool context?

3. In what situations are art alternatives offered? What are the nature of these alternatives? In what situations are art alternatives limited? What is the nature of these limitations?

4. When preschool children have an opportunity to choose among art alternatives, what are their characteristic responses? What are the factors that influence their responses?

5. When preschool children encounter limitations on their opportunity to choose among art alternatives, what are their characteristic responses? What are the factors that influence their responses?

\section{Definition of Terms}

Art Alternatives are options related to making art that are offered by the teacher and by the physical and social environment.

Choice is the opportunity of the power or chance to select among alternatives. (McNairy, 1981).

Art Choice is the opportunity of the power or chance to select among art alternatives. 
Art Limits are factors related to art making that hinder the opportunity of the power or chance to select among art alternatives.

\section{Methods and Methodology}

A naturalistic stance was appropriate for this study for several reasons. First, the purpose of the study was to understand what art alternatives were actually present within a preschool context and how children responded to these within the context (Alexander, 1981). Second, the research questions dealt with meaning rather than with measurement or prediction (Lincoln \& Guba, 1985). Third, the naturalistic method allows researchers to move toward generating theory that is grounded in data obtained from the actual context (Glasser \& Strauss, 1967).

Data collection methods used in this study were participant observation (Pohland, 1972), informant interview (Spradley, 1979), and document analysis (Schatzman \& Strauss, 1973). Data were analyzed by the Constant Comparative Method (Glasser \& Strauss, 1967). Procedures were adopted to verify findings. Adult participants were asked to respond to findings to balance observer bias (Lincoln \& Guba, 1985). Photographs of children's activities and of the preschool context were taken as documentation (Stockrocki, 1985).

\section{Findings for Question 1}

Art activities within this preschool setting can be categorized in three ways; by the media used, the art form stressed, and the organization or structure of the activity. In this study media referred to the materials 
used in the art activity. An inventory of available materials is included in the document. Art form refers to how the material is used. For example, tempera paint may be used for the art form of painting or the art form of printing. In this study it seemed reasonable to consider as art forms those activities common to preschool that are regarded as art by participants. Because of difficulties in interviewing children in this age group, the teachers' view of what constituted an art activity was used in identifying art forms. A list of art forms found in the context and a description of characteristic use within the context were included in this study. Organization referred to who planned the activity, who defined the activity and who participated in the activity. Art activities can be Teacher Organized; that is, planned by a teacher, materials set out by a teacher, activity defined by a teacher and explained to children by teacher or other adult. Art activities can be Child Organized; that is, planned by a child or group of children, materials selected by children from environment, activities defined by children and sometimes explained by them. Children can participate in Child Organized activities as individuals working alone (Solitary) or as a team working together (Joint). Variations of these types of activities are described and discussed in the study in terms of their relationship to artistic choice.

\section{Findings for Questions 2 \& 3}

Art alternatives and limits in this context were categorized by what is offered or limited, where the alternative or limit originated, (Fig. 1\& 2) 
and how the alternative or limit was communicated (Fig. 3). What was offered or limited were materials, processes, subject/themes, and design ideas and their availability or non-availability for children's use. The materials category dealt with media or tools, the processes category dealt with ways of using materials and tools, the subject/theme category dealt with meanings of a work of art, the design category dealt with arrangements of visual qualities.

These various types of alternatives and limits may have originated from different sources. They may have originated from the individual child as a Personal alternative or limit, from the context as an Environmental alternative or limit, from another child or group of children as a Peer alternative or limit, or from a teacher, aid, or parent-teacher as an Adult alternative or limit. These alternatives were made available or limited by certain factors: personal alternatives by a child's knowledge or ability, or lack of knowledge or ability, to do something they wish to do; environmental alternatives by the arrangement and structure of the environment; peer alternatives through interaction with peers; and adult alternatives through interaction with adults.

Communication dealt with how children become aware of alternatives and limits. I chose to focus on interaction with peers and adults for several reasons. First, it is difficult to detect how and when personal and environmental alternatives are communicated to a child. It is impossible to detect when or why a child makes a choice unless the child verbalizes or makes some overt behavior. It is difficult to interview young 
children without influencing their responses. Also, preschool children often are not aware of their reasons for making choices. Therefore peers and adults were focused upon because communications of alternatives and limits tend to involve language or actions that are observable. Alternatives and limits are communicated to children verbally and non-verbally. Verbal means of communication included questions, statements, and various types of conversations. Nonverbal communication of alternatives and limits included direct modeling, indirect modeling, and directive actions.

\section{Findings for Questions 4 \& 5}

Preschoolers in this context responded to art alternatives by attempting to define them, accepting them, or resisting them (Fig. 4). Attempts to define alternatives and limits included such actions as asking questions of an adult to clarify the available alternatives (i.e., "What are the markers for?", "Can I make this into an airplane?") or negotiating with a peer to come to a mutual agreement about the boundaries of an activity (i.e., "We don't like white, right?"). Acceptance resulted in children complying with alternatives exactly as communicated (i.e., copying a "kitty cat" that a parent-teacher drew) or redefining the alternative (i.e., copying the "kitty cat" but drawing an open mouth with teeth instead of the parentteacher's drawing of a cat with a closed mouth). Resistance resulted in children's ignoring an offered alternative (i.e., walking away when asked if they would like to participate in a process) or rejecting an offered 
alternative (i.e., saying "No" when presented with various colors they might use).

Preschoolers in this context responded to art limits by accepting them or resisting them (Fig. 5). Acceptance resulted in complying with the limit as given (i.e., only drawing things we get food from on a banner titled "Where We Get Food") or redefining a situation (i.e., a child who is unable to draw a star the way he wanted saying that his resulting work is "his own kind of star"). Resistance results in ignoring a limit (i.e., an adult tries to get a child to draw something he has seen at a pioneer exhibit, the child remains quiet as she asks questions about the exhibit then asks if she wants him to draw a race car), rejecting a limit with overt response (i.e., child shakes head "No" when adult tries to get him to change his helicopter to an octopus so it will fit on the banner of "Where We Get Food"), negotiating (i.e., child tries to convince adult to give her glitter to put on her bear cave because she's seen bear caves in Africa with glitter on them), and appealing to peers or adults for help in overcoming a limit (i.e., asking an adult to cut some yarn).

\section{Current Research Activities}

At present, I am at the final stages of analysis and moving into a synthesis stage in this study. I am using a database system to do a final sort of collected data. I will be looking for relationships among categories, such as, how alternatives and limits related to particular categories of art activities (media, art form, organization), how responses relate to particular

Working Papers in Art Education 1988 
categories of art alternatives and limits (type, origins, communications), and apparent reasons for alternatives and limits in the context and resulting responses. Memos will be written describing the characteristics of these relationships and will then be synthesized with earlier memos to formulate substantive theory that will add to the knowledge about appropriate balances of freedom and discipline for various art education settings. 


\section{Art Alternatives (Figure 1)}

\begin{tabular}{llll} 
SUBJECT & MATERIAL & DESIGN & PROCESS \\
ALTERNATIVE & ALTERNATIVE & ALTERNATIVE & ALTERNATIVE \\
\hline
\end{tabular}

\section{PERSONAL ALTERNATIVE:}

$\begin{array}{llll}\text { Personal } & \text { Personal } & \text { Personal } & \text { Personal } \\ \text { qualities } & \text { qualities } & \text { qualities } & \text { qualities } \\ \text { make } & \text { make } & \text { make } & \text { make } \\ \text { subject } & \text { materials } & \text { design } & \text { process } \\ \text { option } & \text { option } & \text { option } & \text { options } \\ \text { available } & \text { available } & \text { available } & \text { available }\end{array}$

*all due to personal knowledge or ability

\section{ENVIRONMENTAL ALTERNATIVE:}

$\begin{array}{llll}\text { Environment } & \text { Environment } & \text { Environment } & \text { Environment } \\ \text { makes } & \text { makes } & \text { makes } & \text { makes } \\ \text { subject } & \text { material } & \text { design } & \text { process } \\ \text { options } & \text { options } & \text { options } & \text { options } \\ \text { available } & \text { available } & \text { available } & \text { available }\end{array}$

*all due to the nature of the environment

\begin{tabular}{llll}
\hline & \multicolumn{2}{c}{ PEER ALTERNATIVE: } \\
Peers & Peers & Peers & \\
make & make & make & Peers \\
subject & material & design & make \\
options & options & options & process \\
available & available & available & options \\
& & available
\end{tabular}

ADULT ALTERNATIVE:

$\begin{array}{llll}\text { Adults } & \text { Adults } & \text { Adults } & \text { Adults } \\ \text { make } & \text { make } & \text { make } & \text { make } \\ \text { subject } & \text { material } & \text { design } & \text { process } \\ \text { options } & \text { options } & \text { options } & \text { options } \\ \text { available } & \text { available } & \text { available } & \text { available }\end{array}$




\section{ART LIMITS (Figure 2)}

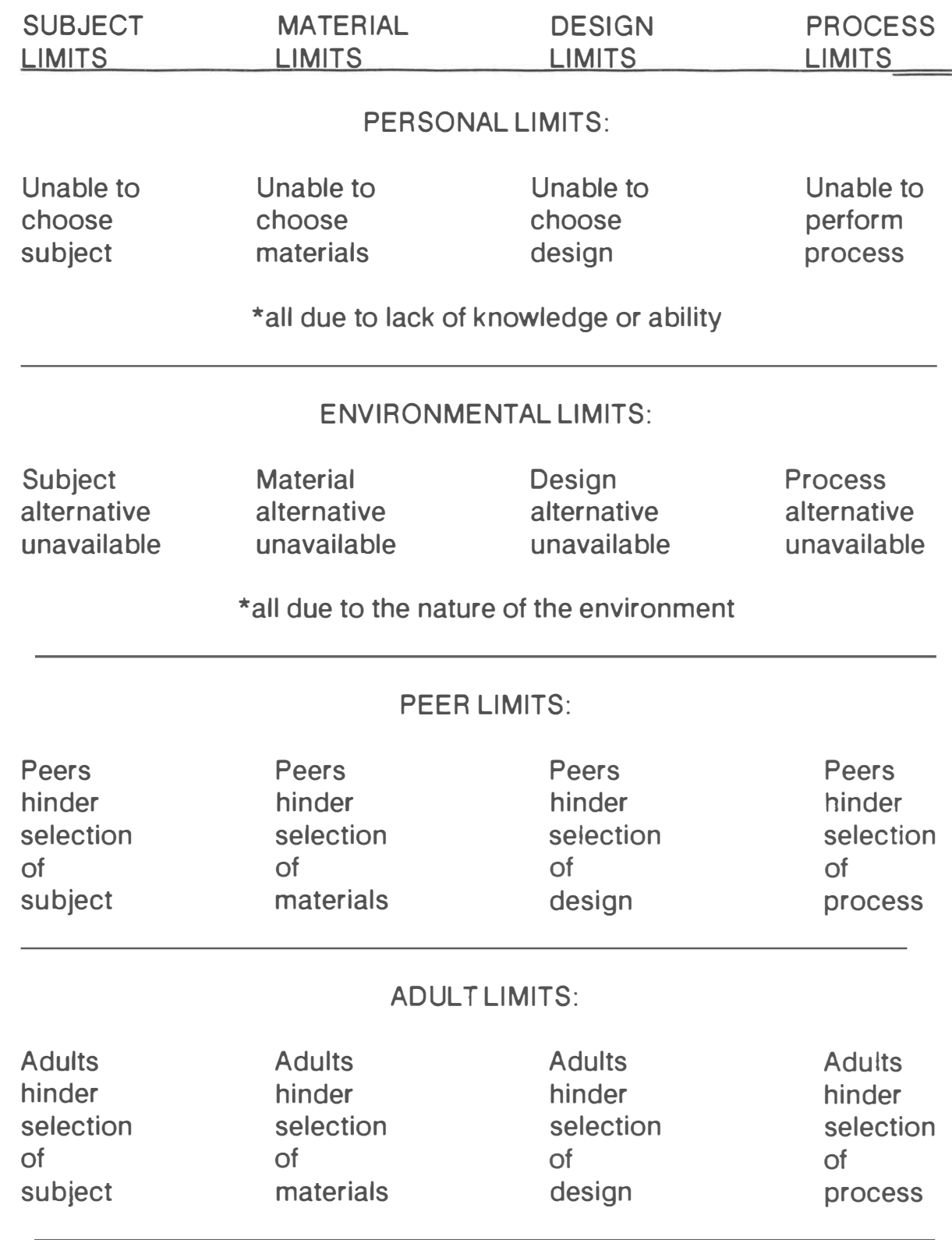


MEANS OF COMMUNICATION OF ALTERNATIVES

USED BY ADULTS AND/OR CHILDREN

(Figure 3)

VERBAL NON-VERBAL

\begin{tabular}{ll}
\hline QUESTION & DIRECT MODELING \\
STATEMENT & INDIRECT MODELING \\
INTERACTION & DIRECTIVE ACTION \\
NEGOTIATION & \\
\hline
\end{tabular}

RESPONSES TO ALTERNATIVES BY PRESCHOOL CHILDREN

(Figure 4)

$\begin{array}{lll}\text { DEFINE } & \text { ACCEPT } & \text { RESIST }\end{array}$

$\begin{array}{lll}\text { ASK QUESTIONS } & \text { COMPLY AS IS } & \text { IGNORE } \\ \text { NEGOTIATE } & \text { REDEFINE } & \text { REJECT }\end{array}$

Working Papers in Art Education 1988 
RESPONSES TO LIMITS BY PRESCHOOL CHILDREN

(Figure 5)

\begin{tabular}{ll}
\hline ACCEPT & RESIST \\
COMPLY AS IS & IGNORE \\
REDEFINE SITUATION & REJECT \\
& NEGOTIATE \\
& APPEAL \\
\hline
\end{tabular}




\section{References}

Alexander, R. R. (1981) The evaluation of naturalistic, qualitative, contextualistic, constructivist inquiry in art education. Review of Research in Visual Arts Education, 13, 1-8.

Barkan, M. (1963). Is there a discipline of art education? Studies in Art Education, 4(2), 4-14.

Cane, F. (1926). Art in the life of the child. Progressive Education, 3 , 155-162.

Clark, G. A., Day, M. D., \& Greer, W. D. (1987). Discipline-based art education: Becoming students of art. Journal of Aesthetic Education, 21 (2), 130-193.

Johnson, P. (1965). Art for the young child. In W. R. Hastie (Ed.) The Sixty-fourth Yearbook of the National Society for the Study of Education. Chicago, IL: University of Chicago Press.

Glasser, B. \& Strauss, A. (1967). The discovery of grounded theory. Chicago: Aldine.

Lazerson, M. (1972). The historical antecedents of early childhood education. In I. J. Gordon (Ed.) The Seventy-first Yearbook of the National Society for the Study of Education. 33-53.

Lincoln, Y. S., \& Guba, E. G. (1985). Naturalistic inquiry. Beverly Hills, CA: Sage Publications.

Lowenfeld, V. \& Brittain, W. L. (1957). Creative and mental growth: Sixth edition. New York: Macmillan.

McNairy, M. R. (1981). The instructional use of choice by a prekindergarten teacher: A descriptive study of a classroom phenomenon from multiple perspectives. (Doctoral dissertation, The Ohio State University, 1981).

Pohland, P. (1972). Participant observation as a research methodology. Studies in Art Education, 13 (3), 4-15.

Schatzman, L. \& Strauss, A. L. (1973). Field Research. Englewood Cliffs, N. J.: Prentice-Hall.

Schwartz, M. S. \& Schwartz, C. G. (1955). Problems in participant observation. American Journal of Sociology, 60, 343-54.

Spradley, J. P. (1979). The ethnographic interview. New York: 
Steele, E. W. (1926). Freeing the child through art. Progressive Education, 3, 168-178.

Stockrocki, M. (1985). Photographic analysis, elicitation, and interpretation as ways of understanding art teaching in a multi-cultural setting. Journal of Multi-cultural and Cross-cultural Research in Art Education, 3 (1), 56-64.

Whitehead, A. N. (1929). The aims of education and other essays. New York: Macmillan. 